\title{
Model Pengembangan Enterpreneurship dalam Pemberdayaan Ekonomi Rumah Tangga di Minangkabau
}

\author{
ZUSMELIA, DASRIZAL, YENI ERITA, RINEL FITLAYENI \\ Pendidikan Sosiologi, STKIP PGRI Sumatera Barat, JI. Gunung Pangilun Padang \\ email: rin31_inzaghi@yahoo.co.id
}

\begin{abstract}
The focus of this research to investigate the women who participate to trade in regional market. It concerns with entrepreneur spirit among Minangkabau societies and explores the relationship between entrepreneurship and economic empowerment either locally and nationally. The presence of women traders is an incubator entrepreneur spirit for next generation. It also contributes to the economic empowerment of West Sumatra in particular and the national. Model development of entrepreneurship spirit in starting a small business and acted by an individual (oneman enterprise), and then put family (family enterprise), evolving toward small companies (small scale enterprise), medium-scale enterprises (medium scale enterprise), and the company (big scale enterprise).
\end{abstract}

Keywords: coordinating, training and field of services to the community

\begin{abstract}
Abstrak. Fokus utama penelitian untuk mengetahui alasan perempuan ikut berdagang di pasar nagari. Bagaimana keterkaitannya dengan lahirnya jiwa enterprenuership serta keterkaitan enterprenuership dengan pemberdayaan ekonomi wilayah Sumatera Barat dan Nasional. Keberadaan perempuan pedagang di pasar nagari merupakan incubator lahirnya jiwa enterpreneurship untuk generasi selanjutnya di Minangkabau sekaligus telah memberikan sumbangan terhadap pemberdayaan ekonomi wilayah Sumatera Barat secara khusus dan ekonomi Nasional secara umum. Model perkembangan jiwa enterpreneurship dimulai dari usaha kecil dan dilakoni oleh individual (one man enterprise), kemudian melibatkan keluarga (family enterprise), berkembang ke arah perusahaan berskala kecil (small scale enterprise), usaha berskala menengah (medium scale enterprise), dan perusahaan besar (big scale enterprise).
\end{abstract}

Kata Kunci: koordinasi, pembinaan, pelayanan, pemberdayaan masyarakat

\section{Pendahuluan}

Dilatarbelakangi oleh semakin kuatnya semangat menyambut gerakan otonomi daerah, di Sumatera Barat ternyata telah membangkitkan ego kultural dengan gerakan "kembali ke pemerintahan nagari," artinya, otonomi daerah dimaknai dengan keinginan untuk kembali dalam sistem pemerintahan nagari yang dianggap sebagai "republik-republik kecil," sehingga euforia kebebasan, dari sistem sentralistik dan kebutuhan akan kedaulatan daerah terpenuhi seketika. Di dalam sistem pemerintahan nagari ini kedudukan perempuan di tengah masyarakat sangat dihargai, yang tercermin dalam mitos "Bundo Kanduang" raja terakhir Minangkabau yang berhasil menyatukan perbedaan antara paham sentralistik dengan paham demokrasi sosial yang telah berurat berakar di tengah masyarakat nagari Minangkabau.
Sejalan dengan kebutuhan tersebut, persoalan yang urgen untuk diselesaikan negara antara lain membangun kembali perekonomian daerah, melalui pemberdayaan perekonomian masyarakat nagari. Hal ini hanya bisa diwujudkan dengan menggali kembali potensi ekonomi nagari yang menjadi basis perekonomian masyarakat nagari. Potensi ekonomi yang menjadi pilar untuk membangun kembali perekonomian nagari adalah pasar nagari yang merupakan cikal bakal lahirnya enterprenuership masyarakat nagari karena terdapatnya perempuan pedagang khusus pada tanaman tua (cassiavera).

Keberadaan perempuan pedagang di pasar nagari sebagai pedagang pengumpul pasar nagari dan pedagang besar tingkat kabupaten untuk tanaman ekspor seperti kayu manis (cassiavera) dan gambir ternyata telah membuat ekonomi rumahtangga masyarakat nagari telah mampu bertahan dalam menghadapi persaingan global 
yang berasal dari supra nagari. Faktanya, monetisasi yang telah sampai ke tingkat rumahtangga petani, sebagai salah satu bias dari kekuatan ekonomi global tidak bisa kita pungkiri tentu akan membawa perubahan dalam posisi perempuan di tengah ekonomi keluarga, baik sebagai penopang utama ekonomi keluarga ataupun sebagai strategi bagi pengamanan pangan dan gizi keluarga saja.

Disampng itu, terjunnya perempuan dalam aktivitas perdagangan tanaman tua yang selama ini selalu di dominasi oleh kaum laki-laki menjadi ketertarikan peneliti memfokuskan penelitian ini di Pasar Nagari Baso di Kabupaten Agam, Pasar Nagari Tabek Patah di Kabupaten Tanah Datar, dan Pasar Nagari Pangkalan di Kabupaten 50 Kota. Kabupaten Datar dan Kabupaten Agam dipilih karena hampir $80 \%$ tata niaga atau perdagangan kayu manis dilakukan di daerah ini. Di sisi lain umumnya di daerah penelitian tanaman ini telah menyatu dengan nilai-nilai budaya masyarakat terutama menyangkut adat istiadat perkawinan, artinya setiap memulai ikatan perkawinan, seorang calon mempelai pria punya kewajiban untuk menanam sebanyak seribu batang kayu manis di kebun istrinya. Jadi dalam hal ini tanaman kayu manis merupakan tanaman yang selalu di budidayakan oleh masyarakat disana-disamping faktor cuaca yang sangat mendukung itu.

Dari uraian diatas yang menjadi pertanyaan penelitian adalah apa latar belakang perempuan pedagang ikut terlibat berdagang tanaman tua; bagaimana keterkaitan antara perempuan pedagang di pasar nagari dengan lahirnya jiwa enterprenuership masyarakat Minangkabau; keterkaitan enterprenuership dengan pemberdayaan ekonomi wilayah Sumatera Barat dan Nasional; serta menemukan model pengembangan enterprenuership masyarakat matrilineal Minangkabau yang mendorong penguatan ekonomi daerah dan Nasional umumnya.

Pasar nagari tradisional Minangkabau sebagai tempat pemasaran tanaman tua sejak abad ke 19 telah terlibat langsung dengan mekanisme ekonomi global dan melalui pasar lokal (pasar nagari). Konsekwensinya secara bersamaan tiga cara produksi (mode of production) hadir sekaligus dengan cara dan orientasi yang berbeda, yakni pertama, cara produksi subsistensi dimana hasil pertanian tanaman pangan dan tanaman perkebunan dengan hubungan produksi yang terbatas dalam lingkup keluarga inti dan hubungan keluarga yang bersifat egaliter. Kedua, Petty commudity dimaksudkan sebagai cara produksi yang sudah berorientasi pasar dengan hubungan produksi yang menunjukkan adanya gejala eksploitasi surplus melalui ikatan kekerabatan dan hubungan sosial antar pekerja. Ketiga, cara produksi kapitalis, yaitu sebagai usaha yang padat modal dengan orientasi pasar, dimana hubungan produksi mencakup struktur majikan-buruhaa atau hubungan dalam bentuk owner dan laborer menurut Khan (1980). Bahkan menurut Nugroho (2001) produksi dan transaksi di pasar sekarang ini telah memperlihatkan terjadinya transaksi dalam bentuk rasionalisasi dalam kehidupan ekonomi yang menempatkan semangat "cost-benefit calculation" sebagai landasan utama dalam berperilaku. Ini dikatakan sebagai sesuatu yang berubah dari cara produksi subsistensi yang berorientasi kecukupan.

Untuk komoditi ekspor di pasar nagari sekarang ini, bentuk produksi yang didasarkan kepada subsisten, petty commodity dan produksi kapitalis, ternyata pada beberapa daerah cenderung didominasi oleh perempuan pedagang (woman traders). Pada hal sebelumnya pekerjaan pedagang selalu identik dengan domainnya pekerjaan laki-laki, terutama untuk komoditi tanaman tua. Penelitian tentang peranan perempuan pedagang di pasar nagari Minangkabau ini terasa masih relatif baru, karena belum ada sejauh ini penelitian yang dilakukan untuk melihat keberadaan perempuan pedagang ini di pasar nagari. Apakah faktor yang melatar belakangi perempuan terjun sebagai pedagang di pasar nagari, bukankah perempuan dalam terminologi budaya Minangkabau posisinya sangat dihargai tinggi yang tercermin dalam mitos budaya mereka tentang peranan "bundo kanduang" dalam sistem pemerintahan dan sistem sosial politik mereka.

Tingginya persentase perempuan bekerja di sektor perdagangan juga telah disinyalir oleh Levin, (1999) dalam studinya tentang perempuan pedagang di Accra, Ghana, Afrika. Perempuan terjun ke sektor perdagangan disamping menyeimbangkan tugas-tugas utama mereka dalam pekerjaan rumahtangga, sebagai ibu dalam pengasuhan anak, dan sumber pemasukan pendapatan keluarga. Perempuan yang berkerja di sektor perdagangan ini mencapai 60 sampai $80 \%$, studi ini juga memperlihatkan peranan penting perempuan meningkatkan pendapatan keluarga sangat dominan. Artinya, perempuan pedagang telah mampu menjadi penopang utama ekonomi rumahtangga mereka, baik sebagai orang tua tunggal, maupun sebagai penopang pendapatan suaminya.

Perempuan telah memainkan peranan penting dalam sistem perekonomian terutama di wilayah pedesaan, terutama mengontrol sejumlah aktifitas besar pasar pedesaan dan perdagangan komoditi ekspor. Menurut Penelitian Haddad (1993) perempuan pedagang telah mampu menjadi alternatif bagi strategi bertahan hidup dari kesulitan ekonomi rumahtangga pedesaan, dimana 
perempuan telah terjun dan ikut membantu kesulitan ekonomi rumahtangga dengan menjadi pedagang di pasar tradisional, bahkan menjadi pedagang keliling di pedesaan.

Sebagai seorang ekonom Neo-Austrian Weberian, Chamlee-Wright (2000), melakukan studi tentang Market Woman di Zmbabwe dan Ghana, yang ingin melihat tentang saling hubungan yang kompleks antara politik, masyarakat dan ekonomi, dengan mengembangkan dan berhasil merangkul konsep embeddedness yang kemudian mampu memberikan informasi yang kaya tentang analisis embededdness bagi market women di Z $\mathrm{Zm}$ babwe dan Ghana. Ditemukan bahwa hambatan sosial-ekonomi, budaya, politik telah menyebabkan entrepreneur perempuan susah untuk berkembang, dan bahkan sama sekali tidak memberi tempat bagi perempuan untuk berhasil di kota Harare.

Dikatakan bahwa di Zimbabwe, diantara orang-orang Shona yang diteliti, adalah masih umum bagi si pelamar laki-laki untuk menawarkan keluarga bakal calon istrinya pada "Labola," yaitu untuk membayar harga diri: "calon suami diharapkan untuk memberikan pengorbanan yang berarti untuk keluarga calon istrinya. Secara tradisional, sebuah perkawinan masyarakat Shona ditempatkan dalam suatu proses yang panjang. Besar kecilnya hadiah yang diberikan mengindikasikan derajad perhatiannya, kemudian diikuti oleh pembayaran/pemberian dalam bentuk ternak lembu, dalam rangka untuk memeroleh hak seksual dan terakhir hak untuk kebanggaan tambahan tenaga kerja sebagaimana si istri bergerak ke rumah suaminya." Budaya seperti ini ditemukan secara umum di dalam masyarakat patrilineal di sepanjang Afrika sub Sahara.

Selanjutnya, Wright mengemukakan, Karena Implikasi ekonomi dari perkawinan, bagi keluarga si perempuan-tidak seperti matrilineal society dimana sesudah perkawinan itu sama sekali masih mungkin perempuan untuk terus berkontribusi secara ekonomi pada keluarga dimana ia dilahirkan - disekitar wilayah Shona, antara keluarga dan harga diri menjadi hal yang kedua (sekunder) setelah ia menikah. "Labola" kelihatannya dapat dibayar dalam masyarakat Shona, karenanya dipandang sebagai suatu kompensasi bagi keluarga perempuan untuk kehilangan materi yang mereka derita sesudah menikah, karena diberikan pada "Labola”. Sehingga dikatakan bahwa implikasi sosial dan politik dari fenomena yang dikondisikan secara ekonomi ini adalah amat besar.

Otonomi politik dan ekonomi perempuan, kapasitasnya untuk berespon pada penyalahgunaan atau pengabaian oleh suaminya dan kontrol si perempuan atas sumberdaya yang dimilikinya dan anak-anaknya semuanya sangat ditentukan oleh labola yang dibayar dan membentuk perkawinan mereka. Sehingga Labola juga bertindak, sebagai penghalang pada perkembangan dinamika kelompok perempuan entrepreneur di Zimbabwe dan Ghana menurut Wright (2000) dalam Boettke dan Storr (2002).

Penelitian ini mengarah pada pendekatan kualitatif (qualitative approach), dengan informasi yang bersifat subyektif dan historis. Penelitian ini multi metode antara lain: (1) metode sejarah sosiologis dengan pendekatan studi riwayat hidup, untuk melihat keberadaan perempuan di pasar nagari dan bagaimana terjadinya proses pentransferan jiwa enterprenuership baik secara value maupun knowledge yang terjadi ditengah keluarga perempuan pedagang dalam bentuk keluarga inti (nuclear family) maupun keluarga besar (extended family); (2) metode interpretative hermeneutik, ini berangkat dari asumsi bahwa aktifitas perempuan pedagang adalah suatu realitas yang sangat dipengaruhi oleh faktor-faktor seperti politik, sosial-kultural, sehingga dibutuhkan berbagai metoda dalam mendekati fenomena yang ada.

Penelitian ini menggunakan dua jenis data yakni data primer dan data sekunder. Data primer merupakan data yang diperoleh dari hasil wawancara mendalam (indept interview) dengan perempuan pedagang dengan menggunakan catatan lapangan dan pedoman wawancara. Data sekunder adalah data dan dokumen yang diperoleh dari instansi terkait seperti Dinas Koperindag, Dinas pertanian, BPS dan lainnya yang dapat memberikan sumber informasi bagi kondisi sosial ekonomi perempuan pedagang sampel dan sektor penyumbang pertumbuhan ekonomi Sumatera Barat.

Adapun teknik pengumpulan data yang digunakan adalah observasi, dan wawancara mendalam (indept interview) dengan menggunakan alat perekam dan membuat pedoman wawancara untuk menelusuri faktor penyebab keterlibatan perempuan pedagang di pasar nagari dengan demikian akan dapat dilihat bagaimana jiwa dagang (enterpreneurship) didapatkan dan diturunkan kepada generasi berikutnya didalam sebuah keluarga di Minangkabau serta bagaimana usaha yang dilakukan dapat dikembangkan sejalan dengan pengembangan jiwa dagang itu sendiri.

Populasi dalam penelitian ini adalah perempuan pedagang di pasar nagari yang membeli hasil pertanian penduduk terutama hasil perkebunan yang menjadi komoditi ekspor. Sampel diambil dari beberapa orang perempuan pedagang dari daerah penelitian. Jumlah sampel perempuan pedagang di daerah Baso sebanyak 32 orang, dari daerah Tabek Patah sebanyak 20 orang sedangkan untuk daerah Mangilang 
sebanyak 5 orang.

Penelitian ini dilaksanakan di pasar nagari

Tabek Patah kabupaten Tanah Datar, di pasar nagari Baso kabupaten Agam, dan pasar nagari Pangkalan kabupaten 50 Kota yang dipilih secara sengaja (purposive sampling) dengan alasan ketiga pasar ini merupakan pasar nagari yang menggelar komoditi eksport utama Sumatera Barat dan dalam perdagangan komoditi tersebut ditemukan banyak perempuan pedagang, sementara di pasar nagari lainnya cendrung di dominasi oleh kaum laki-laki.

\section{Perempuan Pedagang di Pasar Nagari}

Perempuan pedagang untuk komoditi eksport terutama tanaman tua pada beberapa pasar nagari di wilayah Sumatera Barat telah memperlihatkan keterlibatan yang sangat berarti seperti kayu manis, kopi serta gambir. Ada beberapa faktor yang melatar belakangi perempuan terlibat perdagangan tanaman tua. Pertama karena ingin melanjutkan kehidupan keluarga, karena ditinggal oleh suami baik karena di tinggal merantau maupun ditinggal mati. Pada umumnya generasi pertama perempuan pedagang menjadi pedagang adalah karena ditinggal suami, sehingga mengambil tanggungjawab untuk menafkahi keluarga. Generasi setelah itu menjadi pedagang karena warisan orang tua terutama ibu yang telah menjadi enterpreneur untuk menafkahi keluarga, pada tahap ini suami juga telah ikut berdagang dan menjadikan perdagangan sebagai andalan pendapatan keluarga $(71,92 \%)$.

Faktor kedua, perempuan menjadi wirausaha pada generasi pertama adalah ketimpangan kepemilikan lahan pertanian yang dikuasai dan dikelola. Rata-rata kepemilikan lahan pertanian keluarga pedagang di pasar nagari ini hanya 0,25 ha, jauh dibawah rata-rata kepemilikan lahan di Minangkabau yang mencapai 0,7 ha. Kecilnya kepemilikan dan penguasaan lahan ini telah memicu perempuan terjun ke sektor publik ini. Kekurangan kapital fisik ini, tentunya sejalan pula dengan kurangnya modal usaha, sehingga pada umumnya perempuan pedagang pada tipe ini pada awalnya memiliki jumlah modal yang kecil, sehingga perempuan pedagang ini dikelompokkan pada kelompok pedagang bermodal kecil, dengan sebutan "cingkariak" di pasar nagari Baso $(21,87 \%)$ dan "palantuak" di pasar nagari Tabek Patah (30\%). Dalam perjalanan waktu, karena mampu melakukan akumulasi capital dengan baik, sehingga, generasi keduanya, telah memiliki modal yang cukup untuk menjadi pedagang pengumpul dan menjadi usaha dagang keluarga.

Ketiga, faktor pendidikan yang rendah dengan rata-rata tingkat pendidikan hanya tamat sekolah dasar (SD) pada umumnya terjadi pada generasi pertama perempuan terjun ke pasar nagari $(75 \%)$, pada generasi kedua, rata-rata pendidikan sudah sekolah menengah pertama (SMP) dan sekolah lanjutan atas (SMA).

Keempat, asal suku perempuan pedagang ternyata juga menentukan dalam mendorong keterlibatan perempuan menjadi pedagang pada generasi pertama. Data menunjukkan bahwa mayoritas peerempuan pedagang di pasar nagari Baso berasal dari suku Caniago sebanyak 9 orang atau sebesar $28,12 \%$, sedangkan di pasar nagari Tabek Patah didominasi juga oleh suku Caniago sebanyak 8 orang atau sebesar $40 \%$. Artinya dapat dikatakan bahwa faktor suku terutama kelarasan Bodi Caniago menjadi faktor pemicu dan menjadi pembenaran keterlibatan perempuan untuk terlibat pada aktifitas di sektor publik seperti berdagang di pasar nagari pada generasi pertama ini. hal ini tentu saja berkaitan dengan karakteristik kelompok kelarasan Bodi-Caniago yang menganut paham egaliter, demokratis dan mudah menerima perubahan.

Keterlibatan perempuan pedagang di pasar nagari justru yang memunculkan transfer of knowledge dan transfers of values ditengah keluarga inti maupun keluarga besar. Artinya, keterlekatan perempuan pedagang dengan sistem kekarabatan dan ekonomi moral yang dianut, disamping keinginan untuk bertahan dari tekanan ekonomi supra lokal telah memunculkan jiwa enterprenuarship di tengah keluarga inti dan keluarga besar. Kekerasan simbolik dan struktural yang mereka alami di pasar nagari, justru telah menjadi leverage factor untuk memainkan peran yang sama di dalam menguasai perdagangan tanaman tua di pasar nagari kelak dikemudian hari oleh generasi sesudahnya (anak dan keponakan). Sehingga keinginan untuk melakukan akumulasi kapital yang lebih besar, disamping livehood staretegies telah menjadi motivasi instrik untuk melakukan mobilitas sosial yang mereka impikan.

\section{Keterkaitan Perempuan Pedagang dengan Lahirnya J iwa Enterpreneurship}

Melihat keterkaitan perempuan pedagang dan terbangunnya jiwa enterpreneurship di dalam sebuah keluarga di Minangkabau ternyata dari 57 orang sampel perempuan pedagang yang ditemui di pasar nagari memperlihatkan bentuk pengembangan usaha dagang dalam dua tahap yakni: (1) perkembangan usaha dagang dalam konteks enterpreneur yang di mulai dari usaha kecil dan menengah yang dilakoni oleh bentuk usaha individual (one man enterprise) dan kemudian terus melangkah ke usaha yang dilakukan melibatkan keluarga (family enterprise); (2) terlihat pada titik usaha keluarga inilah masa yang paling menentukan, hal ini disebabkan pertama untuk 
berkembang ke arah perusahaan berskala kecil (small scale enterprise), usaha berskala menengah (medium scale enterprise), dan perusahaan besar (big scale enterprise). Kedua, usaha yang dilakukan adalah family enterprise, artinya keterlibatan keluarga baik dalam nuclear family atau extended family itu akan memengaruhi kemajuan dan perkembangan usaha yang dilakukan sebuah keluarga merupakan untuk mempersiapkan generasi penerus untuk keberlanjutan usaha keluarga di masa depan. Artinya pendidikan enterpreneur sudah dimulai di tengah keluarga bisnis ini, dan keberhasilan atau keberlanjutan usaha keluarga ini sangat ditentukan oleh peran I bu dan Bapak dalam menulari jiwa bisnis kepada anak-anaknya. Pengalaman dalam mengelola bisnis keluarga dan pendidikan karakter orang tua sangat menentukan arah, terbangunnya jiwa enterpreneur di tengah keluarga di Minangkabau. Sebanyak $80 \%$ dari sampel menjelaskan bahwa mereka menurunkan cara berdagang dan pengembangan mereka itu sangat dipengaruhi oleh pendidikan yang diberikan oleh orang tua mereka sebelumnya.

Lahirnya Enterpreneur Minangkabau, sebenarnya berasal dari aktifitas bisnis perorangan dan usaha keluarga di pasar nagari. Mayoritas pedagang di pasar nagari di daerah penelitian dilakukan bukan hanya oleh usaha perdagangan perorangan, tetapi juga usaha perdagangan keluarga (extended family). Hal ini terlihat dari usaha perdagangan yang dilakukan merupakan warisan dari generasi sebelumnya seperti ibunya atau kakek dan neneknya, lihat Tabel 1.

Dominasi perempuan pedagang di dalam perdagangan komoditi ekspor ini memperlihatkan bahwa jiwa enterpreneurship masyarakat ditulari dari orang tua (family enterprise) sebanyak $71,92 \%$, lebih dominan ibu yang telah terlebih dahulu terjun sebagai pedagang (one man enterprise). Kemudian jiwa enterpreneurship itu berkembang menjadi milik keluarga besar (extended family) yang diperlihatkan oleh cukup dominannya keluarga besar seperti saudara, paman, nenek yang dahulu adalah pedagang, dan saat ini masih diteruskan oleh generasi sesudahnya sebanyak $38,70 \%$. Biasanya, kelompok inilah yang kemudian menjadi kelompok bisnis kecil di wilayah pedesaannya (small enterprise). Hal ini sejalan dengan yang dikemukakan Khan 1980, ini lebih berorientasi "kecukupan." Artinya, enterpreneurship yang dimulai dari usaha individual yang dirintis oleh perempuan di tengah keluarga, kemudian akan menjadi cikal bakal lahirnya usaha dagang keluarga, apabila kemudian hari telah pula mengikutkan anggota keluarga dari extended family, maka inilah yang kemudian berkembang menjadi small enterprise, yang oleh Khan 1980 yang disebut dengan petty commodity yang sudah berorintasi pasar dengan hubungan produksi telah menunjukkan adanya gajala eksploitasi surplus melalui ikatan kekerabatan dan hubungan sosial antar pekerja.

Pada tahap small enterprise bukan hanya kemampuan untuk dapat akses ke sumber permodalan, tetapi juga adalah jaringan kerja dengan sesama pelaku bisnis lainnya. Disini dibutuhkan kemampuan berkomunikasi yang baik, membangun rasa saling percaya diantara lingkup bisnis, membangun ikatan kelompok (clik member) dalam bentuk in group dengan sesama pedagang. Semua karakteristik perilaku yang dibutuhkan untuk melangkah ke tahap small enterprise ini dominan dipicu oleh telah terakumulasinya knowledge capital dan fisical capital.

Usaha bisnis komoditi eksport pada tahap medium scale enterprise dan big scale enterprise di daerah penelitian pada umumnya dilakukan oleh eksportir, pelaku bisnisnya lebih besar didominasi oleh para pengusaha China. Kelompok usaha bisnis pribumi pada tahap ini hanya satu pada satu kabupaten. Pada kabupaten Tanah Datar yang dapat dikategorikan sebagai medium scale enterprise adalah H.WN dengan PT GKSBO. Perusahaan

Tabel 1.

Karakteristik Pedagang Perempuan di Daerah Penelitian

\begin{tabular}{|llllllllll|}
\hline No & Pasar Nagari & $\begin{array}{l}\text { Jumlah } \\
\text { pedagang } \\
\text { perempuan } \\
\text { (orang) }\end{array}$ & $\begin{array}{l}\text { Rata-rata } \\
\text { umur } \\
\text { (tahun) }\end{array}$ & $\begin{array}{l}\text { Total } \\
\text { Volume } \\
\text { Pembelian } \\
\text { (ton) }\end{array}$ & Ibu & Ayah & $\begin{array}{l}\text { Cikal bakal usaha (\%) } \\
\text { Ibuah }\end{array}$ & $\begin{array}{l}\text { Kel. } \\
\text { besar }\end{array}$ \\
\hline 1. & Tabek Patah & 20 & 37 s/d 54 & 2,1 & 6 & 2 & 7 & 5 \\
2. & $\begin{array}{l}\text { Baso } \\
\text { Mangilang }\end{array}$ & 32 & 33 s/d 56 & 13 & 10 & 2 & 8 & 12 \\
& Total & 57 & 33 s/d 48 & 3 & 1 & - & 2 & 2 \\
\hline
\end{tabular}

Sumber : Hasil Penelitian 2011 (data diolah) 
ini disamping pemasok ekspor cassiavera dari kabupaten Tanah Datar, juga sebagai pemasok cassiavera untuk kebutuhan dalam negeri seperti dikirim ke Bali. Pada saat ini, pemilik PT GKSBO sudah mempersiapkan generasi kedua, walaupun generasi pertamanya masih ikut aktif dalam menjalankan bisnisnya, tetapi sudah menggunakan manajemen modern karena sistem manajemennya dilakukan oleh manajer yang telah professional.

Generasi pertama perempuan pedagang dalam bisnis tanaman ekspor paling tinggi hanya pada tahap small enterprise, untuk tahap medium dan big enterprise dilakukan oleh generasi kedua perempuan pedagang, terutama anak laki-lakinya. Ada beberapa alasan kenapa generasi pertama perempuan pedagang terbatas aksesnya pada tahap "medium scale enterprise dan big scale enterprise." Pertama, Pada tahap medium scale enterprise pelaku bisnis sudah melakukan interaksi dengan eksportir yang didominasi oleh etnis China di Kota Padang. Komunikasi dengan eksportir yang didominasi oleh etnis China harus lebih inten karena informasi tentang harga komoditi perdagangan diperoleh dari eksportir ini, setidaknya dua kali dalam sepekan interaksi face to face harus dilakukan, agar besarnya kuota ekspor dan fluktuasi harga pasar dapat dipantau, karena akan menentukan penetapan harga di pasar nagari.

Kedua, keterbatasan usia perempuan pedagang, yang rata-rata memulai usaha dagangnya setelah menikah, punya anak, dan ditinggal suami, sehingga merintis usaha bisnisnya sudah diatas usia 30 tahunan. Untuk sampai pada tahap perkembangan bisnis ditingkat small enterprise setidaknya dibutuhkan waktu $15 \mathrm{~s} / \mathrm{d} 20$ tahun. Sehingga untuk mobilitas tinggi dalam menjaga komunikasi face to face yang intens dengan ekportir di Padang mulai terbatas karena usia yang mulai tua. Oleh karena itu, bagi usaha bisnis di tahap small enterprise peran generasi kedua sangat menentukan untuk menjaga komunikasi intens face to face dengan ekportir di Padang.

Ketiga, status perempuan janda pengusaha ini sudah membatasi bisnis perempuan pedagang untuk mengembangkan bisnisnya di luar komunitas budayanya. Mobilitas yang tinggi dan berkomunikasi dengan rekan bisnis dari berbagai kalangan terutama di luar komunitasnya agak sulit dilakukan dengan status tanpa suami, karena perempuan pedagang generasi pertama harus tetap pula menjaga pertimbangan pandangan komunitasnya yang selalu kritis terhadap gerakgeriknya dalam berkomunikasi dan berinteraksi dengan mitra bisnis di luar komunitasnya.

Keempat, sistem nuclear family yang

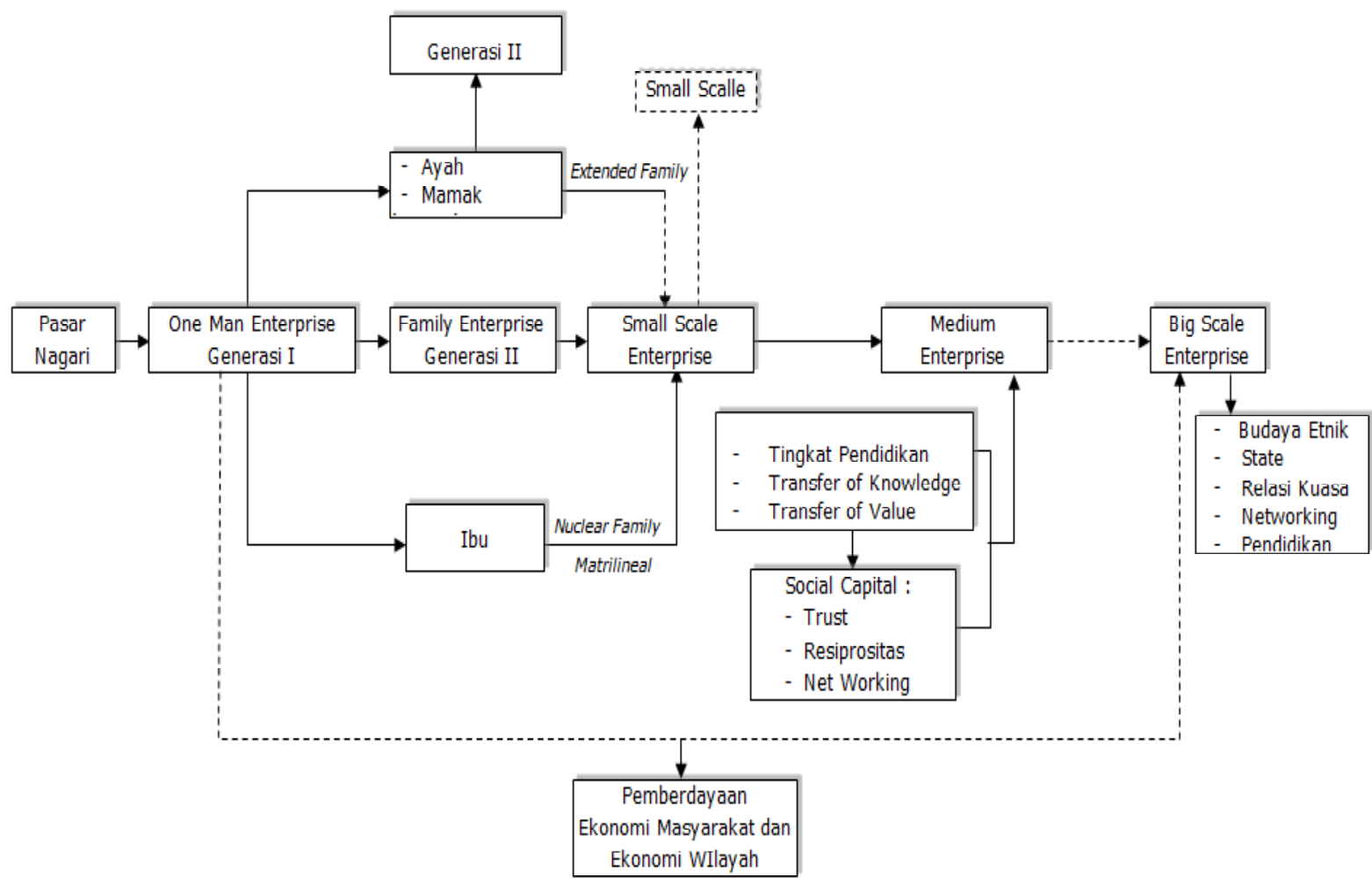

Gambar 1

Model Pengembangan Enterprenuership Dalam Pemberdayaan Ekonomi Rumah Tangga Pada Masyarakat Matrilineal 
melekat dalam identitas perempuan pedagang membatasi kesempatan bisnis yang dijalankan. Keterbatasan anggota keluarga yang hanya pada pihak garis keturunan ibu (sistem matrilineal), sedangkan dari garis keturunan Bapak tidak lagi dapat membantu, telah mengurangi sumberdaya manusia anggota bisnis perempuan pedagang. Sehingga, generasi kedua yang muncul dari perempuan pedagang untuk melanjutkan usaha selalu berasal dari keluarga inti, seperti anak perempuan dengan suaminya atau anak laki-laki dengan istrinya.

Kelima, keterbatasan waktu menyiapkan generasi kedua dan ketiga untuk memperoleh jenjang pendidikan yang layak dan memadai sehingga nantinya dapat mengembangkan bisnis ke tahap medium scale enterprise dan big scale enterprise. Waktu untuk mendidik dan mengawasi anak-anak untuk belajar dan memberikan bimbingan belajar menjadi berkurang, karena lokasi bisnis ada di tengah pasar nagari. Anakanak sejak kecil sudah ikut menemani ibunya berdagang di pasar nagari, dan sudah mulai terbiasa dengan keramaian pasar nagari dengan segala kesenangan (entertainment), dan daya tariknya, sehingga perhatian untuk bersekolah menjadi berkurang dan cenderung kurang menarik dibandingkan dengan daya tarik keramaian di Pasar nagari. Bahkan beberapa anaknya sudah mulai dilibatkan dalam transaksi bisnis sejak dini.

Jadi, perempuan pedagang di pasar nagari telah menjadi incubator bagi munculnya kelompok enterpreneur Minangkabau, data menunjukkan bahwa sebesar $57,14 \%$ responden dari kelompok enterpreneur mengaku jiwa bisnisnya diperoleh dan terinspirasi oleh karena ibunya sebagai pedagang di pasar nagari. Apabila dimasukkan ayah, maka sebesar $85,71 \%$ responden jiwa bisnisnya diperoleh dari orangtua pedagang di pasar nagari. Artinya, generasi kedua dan ketiga perempuan pedagang telah mampu mengembangkan bisnis keluarga family enterprise menjadi medium scale enterprise, dengan jenis usaha yang mulai terdiversifikasi ke jenis usaha lain.

Untuk lebih jelasnya bagaimana keterkaitan perempuan pedagang dengan terbangunnya jiwa enterpreneursehip ditengah keluarga Minangkabau dan kemudian melahirkan pemberdayaan ekonomi baik ditingkat rumah tangga maupun ditingkat wilayah dan bagaimana satu sama lainnya terkait atau saling mempengaruhi dalam relasi sosial dan formasi sosial yang terbangun dan berawal dari pasar nagari dapat dilihat pada Gambar 1.

\section{Enterpreneurship dalam Pemberdayaan Ekonomi Sumatera Barat}

Pertumbuhan ekonomi Sumatera Barat lebih besar didorong oleh sektor pertanian, terutama sub sektor perkebunan dan lebih khususnya sawit, karet, kayu manis, gambir, nilai dan lain sebagainya. Pertumbuhan ekonomi Sumatera Barat telah mengalami recovery pada tahun 2010 setelah terjadinya kontraksi akibat terjadinya krisis moneter di negara Amerika Serikat sebagai negara tujuan utama eksport Sumatera Barat dan kejadian bencana gempa 30 September 2009 yang merusak infrastruktur perekonomian, sehingga pertumbuhan ekonomi Sumatera Barat yang semula pada tahun 2009 adalah sebesar 4,16 persen, atas dasar harga konstan tahun 2000, telah mengalami kenaikan yang sangat signifikan menjadi 5,93\%. Produk Domestik Regional Bruto (PDRB) tahun 2010 telah meningkat menjadi Rp 38,66 triliun dari sebesar $\mathrm{Rp} 36,49$ triliun tahun

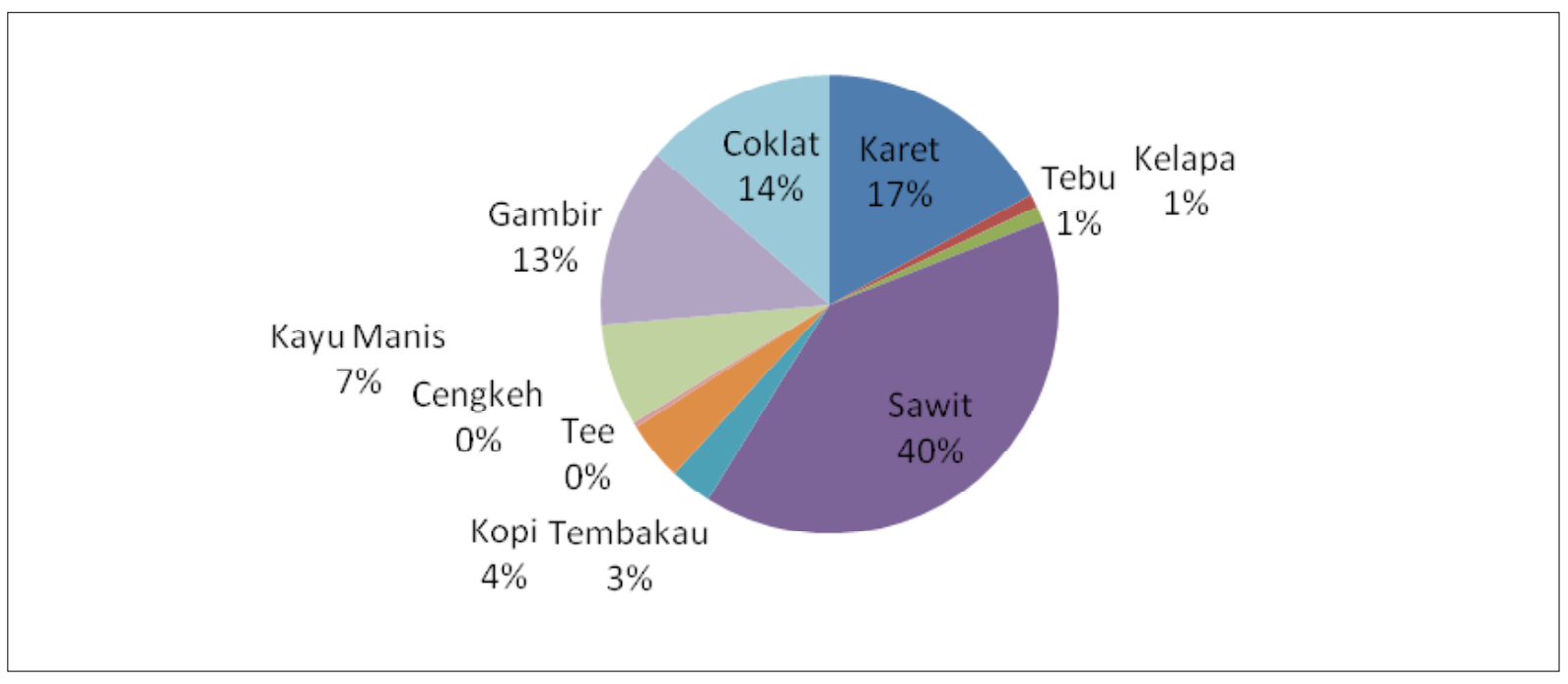

Gambar 2

Perbandingan Nilai Ekspor Komoditi Perkebunan Sumatera Barat 


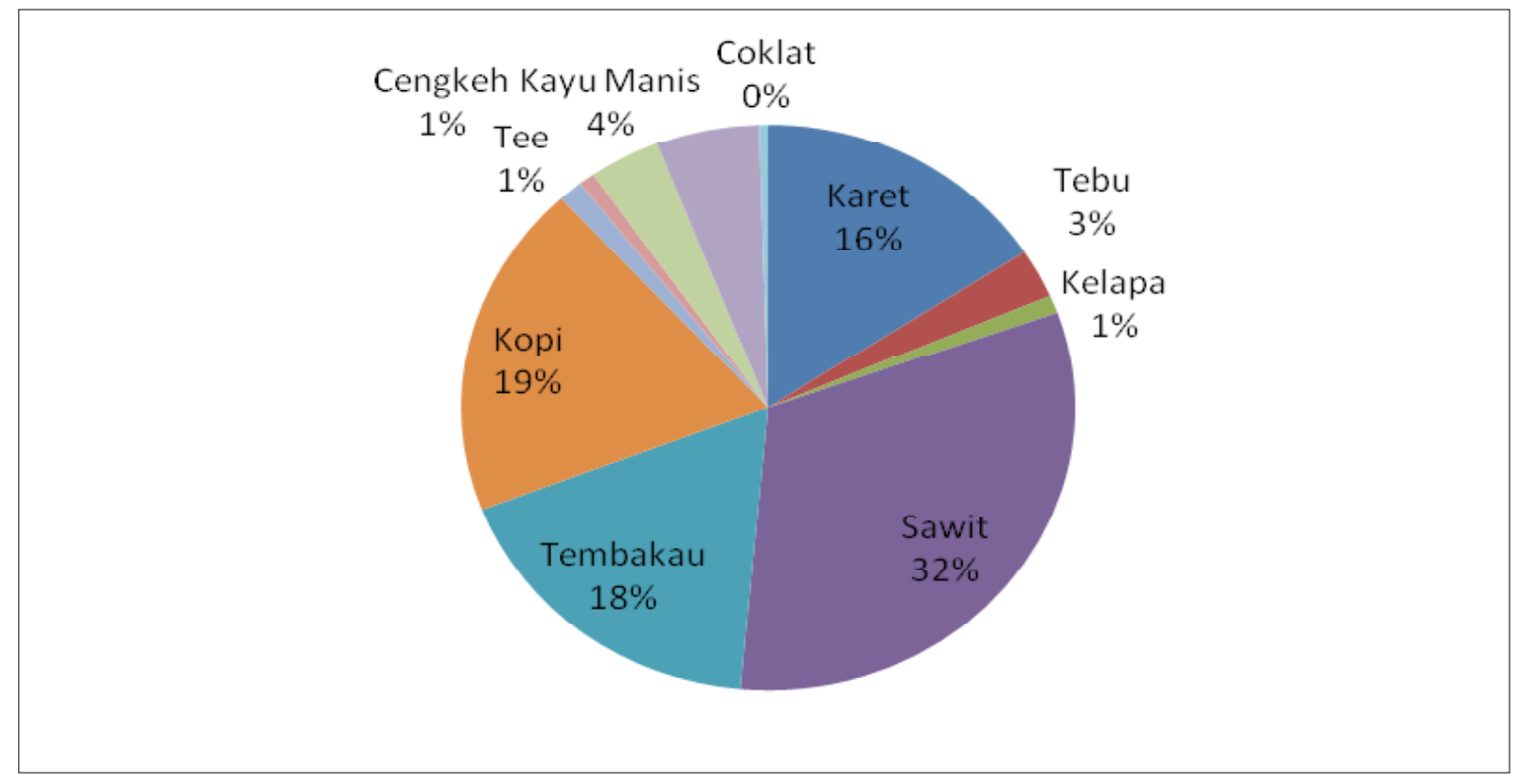

Gambar 3

Perbandingan Besarnya Pajak Tidak Langsung J enis Komoditi Ekpor Perkebunan Sumatera Barat

2009.

Struktur perekonomian daerah sampai tahun 2010 masih didominasi oleh tiga sektor, yakni sektor pertanian $(23,84 \%)$, sektor perdagangan hotel dan restoran $(17.74 \%)$, dan sektor jasa-jasa $(16,03 \%)$. Sehingga kontribusi ketiga sektor ini mencapai lebih dari $57,61 \%$. Perkembangan ini memperlihatkan pentingnya peran sektor pertanian terutama sub sektor perkebunan dan perikanan di samping sub sektor pertanian tanaman pangan hortikultura dan peternakan, di dalam perekonomian daerah Sumatera Barat. Tentunya, besarnya peran subsektor perkebunan ini tidak terlepas dari peran kelompok enterpreneur lokal yang memainkan peranan besar di tingkat pasar lokal sampai ke tingkat eksportir, sebagaimana yang diperankan oleh kelompok pedagang menengah dan besar.

Transaksi subperkebunan terutama komoditi utama yang dilakukan di pasar nagari dilakukan oleh perempuan pedagang sebagai pelaku utamanya. Pada gambar 3 memperlihatkan bahwa diantara komoditi perkebunan yang diperdagangkan di pasar nagari, terutama dilakukan oleh generasi pertama dan kedua dari perempuan pedagang di pasar nagari, yang paling besar untuk dieksport adalah sawit sebesar Rp 822,9 miliar atau sebesar 40\% dari total eksport tanaman perkebunan ini, disusul oleh karet senilai Rp 352,7 milyar atau sebesar $17 \%$, sedangkan gambir dan kulit manis masing-masing adalah sebesar Rp 264,2 milyar atau sebesar $13 \%$ dan Rp 149,3 milyar atau sebesar $7 \%$.

Gambar 2 memperlihatkan bahwa terdapat lima besar komoditi perkebunan Sumatera Barat yang memberikan porsi yang besar terhadap ekspor Sumatera Barat yakni: kelapa sawit 40\%, karet $17 \%$, coklat $14 \%$, sedangkan gambir $13 \%$ dan kulit manis hanya $7 \%$. Sedangkan peran komoditi lainnya relatif kecil nilai ekspornya. Diantara kelima komoditi perkebunan ini yang paling lama memberikan sumbangan terhadap peningkatan ekspor Sumatera Barat adalah karet, kayu manis, gambir, sedangkan sawit dan coklat relatif baru.

Gambar 3 memperlihatkan bahwa komoditi export perkebunan yang memberikan nilai pajak tak langsung untuk peningkatan PDRB Sumatera Barat itu adalah komoditi sawit sebesar Rp 20,73 milyar atau sebesar $32 \%$, disusul oleh kopi sebesar Rp 12,42 milyar atau sebesar 19\%, tembakau Rp 11,47 milyar atau 18\%, karet sebesar Rp 10,21 milyar atau sebesar 16\%. Sedangkan cassiavera hanya sebesar Rp 2,43 milyar atau hanya 4\%, dan gambir adalah sebesar Rp 3,53 milyar atau sebesar $5 \%$. Pajak tidak langsung merupakan pajak yang dikenakan pemerintah untuk setiap transaksi penjualan yang dilakukan oleh perusahaan seperti pajak pertambahan nilai. (PPN). Kecilnya nilai pajak tak langsung dari komoditi eksport perkebunan ini terutama gambir dan kayu manis disebabkan oleh masalah monopsoni kelompok. Hanya sedikit pembeli komoditi cassiavera dan gambir pada level perdagangan tingkat kabupaten dan eksportir, sedangkan pajak tak langsung ditarik dari transaksi perusahaan perdagangan ini, volume transaksi di pasar nagari belum termasuk jenis kena pajak. 
Oleh karena itu, untuk meningkatkan nilai pajak tak langsung dalam perdagangan komoditi ekspor, maka sistem monopsoni kelompok (pasar monopsoni) ini harus dipecahkan, dengan membuka peluang bagi perusahaan baru untuk dapat masuk sebagai pemain pada tingkat kecamatan, kabupaten dan eskportir. Sehingga dengan semakin banyaknya pembeli, diharapkan harga semakin bersaing, bukan memperkuat sistem monopsoni kelompok dan industri. Jika perusahaan perdagangan dan industri pengolahan komoditi perkebunan yang berorientasi ekspor semakin berkembang, tentunya objek pajak tidak langsung akan semakin besar pula, inilah yang mampu memberikan sumbangan yang besar bagi nilai PDRB Sumatera Barat.

\section{Simpulan dan Saran}

Terdapat sejumlah faktor mengapa perempuan terjun ke sektor perdagangan tanaman ekspor: (1) karena ingin melanjutkan kehidupan keluarga, karena ditinggal oleh suami baik karena ditinggal merantau maupun ditinggal mati; (2) ketimpangan kepemilikan lahan pertanian yang dikuasai dan dikelola. Rata-rata kepemilikan lahan pertanian keluarga pedagang di pasar nagari ini hanya 0,25 ha, jauh dibawah rata-rata kepemilikan lahan di Minangkabau yang mencapai 0,7 ha. Kecilnya kepemilikan dan penguasaan lahan ini telah memicu perempuan terjun ke sektor publik ini; (3) tingkat pendidikan yang rendah; (4) asal suku perempuan pedagang terutama kelarasan Bodi Caniago yang bersifat egaliter, demokratis dan mudah menerima perubahan.

Keberadaan perempuan pedagang di pasar nagari yang memperdagangkan komoditi ekspor, merupakan incubator bagi lahirnya jiwa enterprenuership ditengah inti dan keluarga besar. Hal ini disebabkan kekerasan simbolik dan struktural yang dialami di pasar nagari, justru telah menjadi leverage factor untuk memainkan peran yang sama di dalam menguasai perdagangan tanaman tua di pasar nagari kelak dikemudian hari oleh genarasi sesudahnya (anak dan keponakan). Sehingga keinginan untuk melakukan akumulasi kapital yang lebih besar, di samping livehood strategies telah menjadi motivasi instrinsik untuk melakukan mobilitas sosial yang mereka impikan.

Peran kelompok enterpreneur lokal secara tidak langsung penyumbang terhadap pertumbuhan ekonomi Sumatera Barat terutama sub perkebunan. Hal ini terkait kontribusi mereka memberikan nilai pajak tak langsung untuk peningkatan PDRB Sumatera Barat itu adalah komoditi sawit sebesar Rp 20,73 milyar atau sebesar 32\%, disusul oleh kopi sebesar Rp 12,42 milyar atau sebesar $19 \%$, tembakau Rp 11,47 milyar atau 18\%, karet sebesar Rp 10,21 milyar atau sebesar $16 \%$. Sedangkan cassiavera hanya sebesar Rp 2,43 milyar atau hanya $4 \%$, dan gambir adalah sebesar Rp 3,53 milyar atau sebesar $5 \%$.

Adapun model pengembangan enterpreneurship dimulai dari usaha sendiri (one man enterprise), kemudian terus berkembang ke arah usaha keluarga (family enterprise). Pada titik usaha keluarga inilah masa yang paling menentukan, pertama untuk berkembang ke arah perusahaan berskala kecil (small scale enterprise), usaha berskala menengah (medium scale enterprise), dan perusahaan besar (big scale enterprise). Family enterprise merupakan masa untuk memersiapkan generasi penerus untuk keberlanjutan bisnis keluarga di masa depan. Pendidikan kewirausahaan sudah dimulai di tengah keluarga bisnis ini. keberhasilan dan keberlanjutan perusahaan keluarga ini sangat ditentukan oleh peran orang tua (ibu dan ayah) dalam menularkan jiwa bisnis kepada anak-anaknya. Pengalaman dalam mengelola bisnis keluarga dan pendidikan karakter orang tua sangat menentukan arah, terbangunnya jiwa bisnis di tengah keluarga di Minangkabau.

\section{Daftar Pustaka}

Boettke, P.J, Storr, V.H. (2002). Post Classical Political Economy: Polity, Society and Economy in Weber, Mises and Hayek, in Moss. L.S (ed), (2002). The New Political Economies: A Collection of Essays from Around The World, Blackwell Publishers, Ltd, United Kingdom.

Creswell, J. W. (1995). 'Research Design: Qualitative and Quantitative Approaches', Sage Publications, London.

Damsar. (2009). 'Pengantar Sosiologi Ekonomi', Kencana Prenada Media Group, Jakarta.

Damsar. (2005). Tanah Ulayat dan Ketahanan Ekonomi Sosial Budaya Masyarakat Minangkabau, 27-28 Agustus. Balitbang Pertanian dan Yapadi Indonesia. J akarta, pp43-56.

Effendi, N. (1999). Minangkabau Rural Markets: Their System Rules and Function in the Market Community of West Sumatra, Indonesia. Dissertasi. Fakultat fur Soziologie der Universitat Bielefeld. German.

Granovetter. M (1990). 'The Old and The New Economic Sociology : A History and Agenda in: Friedland, R and Robertson, A.F, (eds). Beyond the Marketplace Rathiking Economy and Society', Aldine de Gruyter, New York.

Khan, J. (1980). 'Minangkabau Social Formation: Indonesia Peasant the World Economy', Cam- 
ZUSMELIA, DKK. Model Pengembangan Enterpreneurship dalam Pemberdayaan Ekonomi Rumah Tangga ...

bridge University Press, USA.

Manan, I. (1995). 'Birokrasi Modem dan Otoritas Tradisional di Minangkabau (Nagari dan Desa di Minangkabau)', Yayasan Pengkajian Kebudayaan Minangkabau, Padang.

Nugroho, H. (2001). 'Uang, Rentenir dan Hutang Piutang di J awa', Pustaka Pelajar: Yogyakarta.

Putra, H.S.A (2003). 'Ekonomi Moral, Rasional dan Politik dalam Industri Kecil di Jawa: Esei-esei Antropologi Ekonomi', Kepel Press, Yogyakarta.
Sotorus, M.T. (2004). 'Revolusi Coklat: Social Formation, Agrarian Structure and Forest Margin in Upland Sulawesi, Indonesia', Springers, Berlin-Heiderberg, German.

Slater, D and Tonkiss, F. (2001). 'Market Society : Market and Modern Social Theory', Blackwell Publishers Inc, USA.

Tjondronegoro, S.M.P. (2005). Pembangunan, Modal dan Modal Sosial, dalam Jurnal Sosiologi Indonesia No 7/2005 pp 10-14. 